\author{
Military Technical College \\ Kobry El-Kobbah, \\ Cairo, Egypt
}

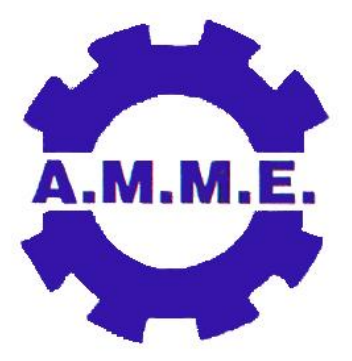

14th International Conference on Applied Mechanics and Mechanical Engineering.

\title{
COTTON, PALM AND FLAX OILS AS ALTERNATIVE FUELS FOR DIESEL ENGINE
}

By

\author{
M. S. SHEHATA *
}

\begin{abstract}
:
Experimental studies have been carried out to investigate effects of biodiesel fuels on diesel engine performance and emissions characteristics. Biodiesel fuels are prepared from cotton seed oil, palm oil and flax oil to use as an alternative fuel for diesel engine. Biodiesel emissions and performance parameters are compared with the base diesel fuel using single cylinder air cooled direct injection diesel engine with and without exhaust gas recirculation (EGR) for different engine speeds. Viscosity and density of different fuels are measured at different temperatures to determine the temperature at which the viscosity has minimum difference between biodiesel and diesel fuels to decrease viscosity effects on the results. The results indicate that biodiesel fuels give slightly less brake power, brake thermal efficiency and slightly higher brake specific fuel consumption and higher fuel mass flow rate per cycle. Diesel fuel gives lower $\mathrm{CO}$ and $\mathrm{CO} 2$ concentrations than biodiesel fuels due to lower carbon/hydrogen ratio and higher heating value. Biodiesel fuels give higher NOX concentrations than diesel fuels due to higher oxygen concentrations in biodiesel molecules and higher cetane number. The main parameters affecting biodiesel fuels combustion are viscosity, density, oxygen content, centane number, heating value and fuel compositions which are the basic parameters for analysis the results. Using EGR increases CO concentrations and decreases NOX concentrations due to decrease flame temperature. Also, exhaust gas temperature (TExhaust), oil temperature (TOil), wall temperature (TWall), cylinder pressure are measured with/without EGR. TExhaust and TOil for biodiesel fuels are higher than that for diesel fuel. TWall for diesel fuel is higher than all biodiesel fuels. Fluctuation in TExhaust is higher than fluctuation in TOil and TWall respectively. Biodiesel fuels give maximum cylinder pressure higher than diesel fuel. The present work contributes in using biodiesel fuels as alternative fuel for diesel engine and decreasing diesel engine emissions. The position of maximum cylinder pressure are arrangement as 11 crank angle (CA) degree after top dead center (ATDC) for flax, 12 CA degree ATDC for cotton, 14 CA degree ATDC for palm and 20 CA degree ATDC for diesel fuel respectively
\end{abstract}

Keywords: Biodiesel fuel, Performance, emission, EGR, palm, cotton, flax 
* Mechanical Engineering Technology Department, Higher Institute of Technology, Benha University, Egypt 


\section{1- Introduction}

A great deal of research effort has been oriented towards the using of vegetable oils and their derivatives as alternative fuels for diesel engine. The advantages of vegetable oils as alternative fuel for diesel engine are (1) Its portability, ready availability, renewability, higher cetane number, lower sulfur content, lower aromatic content, and biodegradability (Bala, 2005).(2) They are biodegradable and contribute to sustainability, (3) They are very environmentally friendly, (4) They are easily available from common sources, and (5) Carbon dioxide cycle occurs in combustion, (6) Better combustion process, (7) Improved lubricity, which partly compensate for the impact of the lower energy content, (8) Biodiesel is nonflammable and, in contrast to diesel fuel, is non-explosive (more safely) a flash point of $423 \mathrm{~K}$ for biodiesel as compared to $337 \mathrm{~K}$ for diesel fuel, (9) Pour points for biodiesel fuels vary from 274 to $298 \mathrm{~K}$ higher for biodiesel fuels depending on the feedstock. (10) Biodiesel is easier to produce and cleaner with equivalent amounts of processing when starting with clean vegetable oil.

The major disadvantages of biodiesel are specific weight and viscosities are higher, lower energy content, higher cloud point and pour point, injector coking, engine compatibility, high price, and greater engine wear. The technical disadvantages of biodiesel/fossil diesel blends include problems with fuel freezing in cold weather, reduced energy density, and degradation of fuel under storage for prolonged periods. One additional problem is encountered when blends are first introduced into equipment that has a long history of pure hydrocarbon usage. Hydrocarbon fuels typically form a layer of deposits on the inside of tanks, hoses, etc. Biodiesel blends loosen these deposits, causing them to block fuel filters. However, this is a minor problem, easily remedied by proper filter maintenance during the period following introduction of the biodiesel blend. Biodiesel oils are characterized by their physical and fuel properties including density, viscosity, iodine value, acid value, cloud point, pure point, gross heat of combustion, and volatility.

Song and Anne (2008) measured $\mathrm{NO}_{x}$ and $\mathrm{CO}$ emissions from large utility generators using diesel/biodiesel blends. Tests were performed using the regular diesel fuel (B0) and biodiesel blends (B10, B20, B100). Test results showed that carbon monoxides decreased significantly as biodiesel content increases, whereas $\mathrm{NO}_{x}$ increased. Tom Beer et. al. (2007) studied the upstream processes of growing and harvesting canola lead to upstream Green House Gases (GHG) emissions that are approximately 3.5 times higher than upstream emissions from refining the diesel fuel. Tallow has upstream GHG emissions that are approximately $50 \%$ higher than the upstream emissions of diesel fuel, whereas those of used cooking oil are slightly lower. Knothe (2005) has reviewed the dependence of biodiesel fuel properties on the structure of fatty acid alkyl esters. The cetane number decreases with increasing unsaturation and increases with increasing chain length, is largest for esters containing 16 carbon atoms and decreases if there are more or fewer carbon atoms. In general, the heat of combustion increases with chain length and for an ethyl ester is greater than the heat of combustion for a methyl ester. Avinash et. al. (2004), Walke et. al. (2008) and hazikhani (2009) carried out experimental investigation to observe the effect of EGR on the exhaust gas temperatures and exhaust opacity. EGR is proved to be one of the most efficient methods of $\mathrm{NO}_{x}$ reduction. One simple way of reducing the $\mathrm{NO}_{x}$ emission of a diesel engine is by late injection of fuel into the combustion chamber. This technique is effective but increases fuel consumption by $10-15 \%$, which necessitates the use of more effective $N O_{x}$ reduction techniques like EGR. 
Recirculating part of the exhaust gas helps in reducing $\mathrm{NO}_{\mathrm{x}}$, but appreciable particulate emissions are observed at high loads. Rajan and Senthilkumar (2009) results showed that for a $7.5 \mathrm{~kW}$ power output, B20 Sunflower methyl ester (SFME) with 15\% EGR rate produces $25 \%$ less $\mathrm{NO}_{x}$ emissions compared to diesel fuel for the same level smoke emissions.

Levent Yüksek (2009) studied biodiesel (rapeseed oil methyl ester RME) as an alternative fuel for diesel engines made from new/used vegetable oils and animal fats. It is biodegradable and has lower hydrocarbon emission levels and similar performance characteristics compared to diesel fuel. Related studies indicate that biodiesel fuel has a potential for reducing engine wear. This experimental study investigates the effect of diesel fuel and RME on lubricating oil performance and the exhaust emissions. Performance, emissions and long-term wear tests were carried out and discussed on a single cylinder marine diesel engine for both diesel fuel and $100 \%$ RME. Results indicated that the RME has a deteriorating effect on lubricating oil performance by decreasing oil viscosity. Ferrous element is the main evidence of the engine wear and it was increased depending on lowering viscosity relating to the fuel dilution and rising running period.

The aims of the present work are to prepared biodiesel fuels from cotton seed oil, palm oil and flax seed oils and measured viscosity/density at different temperature. After that, performance, emissions and combustion characteristics are studied at high fuel temperature using four-stroke, single cylinder, air cooled direct-injection diesel engine with compression ratio of 17:1 to ensure their suitability as alternative fuel for diesel engine.

\section{EXPERIMENTAL SETUP}

The present study is conducted on the engine at the research lab of Higher Institute of Technology, Banha University. The experimental setup is shown in Fig.(1). The engine is a single cylinder, four stroke air cooled with compression ratio of 17:1 direct injection diesel engine. The engine specifications are shown in table (1). Tests were held on a laboratory test bench which includes an electrical dynamometer, coupled to the engine output shaft. It is a DC electric generator (MEZ-BURNO) with maximum electric power output $10.5 \mathrm{~kW}$. An external excitation of electric circuit is used to generate the generator magnetic field. This circuit consists of an AC autotransformer and a rectifier bridge. The DC generator excitation voltage is controlled and adjusted by the autotransformer. The value of excitation voltage is measured using a digital AC voltammeter (Radio-Shack) of $750 \mathrm{~V}$ measurement range and 1 volt resolution. The electric power output from the DC electric generator is consumed in heating water flowing through a water tank. The present system provides a facility to conduct engine performance tests at different values of engine load. The load values are chosen and defined by selecting the generator excitation voltage values. Similarly, the engine is said to be working at a certain load ratio when the excitation field voltage applied on the DC generator is adjusted to produce a ratio of engine output power to full load power at the rated engine speed that is equal to the prescribed load ratio. The values of the excitation field voltage corresponding to the prescribed engine load have been maintained constant over the entire engine speed range during a single experiment. A generator water cooling system has been installed to maintain a constant generator temperature of $25^{\circ} \mathrm{C}$ during all the experiments. This cooling system has been found essential to avoid the effect of generator internal losses on the accuracy of engine power measurements. 
Digital viscometer model 98936-15 manufactured by Cole Darmer Instruments Company with accuracy of $1 \%$ are used for measuring oil viscosity with help of a controlled electrical heater and type $\mathrm{J}$ thermocouple. Also, oil density is measured with help of scaled glass known volume and weight. Instrumentations for measuring engine power, cylinder pressure, fuel consumption, intake air flow rate, engine speed, wall and exhaust temperatures at selected points are included in the test rig. Measurements of engine brake power have been performed by measuring the output DC voltage and current of the DC generator using an analogue voltammeter $(0-300 \mathrm{~V}$ range and $1 \mathrm{~V}$ resolution) and ammeter (0-30) ampere range and $0.1 \mathrm{a}$ resolution. The engine fuel system is modified by adding a custom made tank, and a flow metering system which used for fuel consumption measurement.

A two glass burette of known volume and one 3-way hand operated control valve which allowed rapid switching between the base fuel and the test fuel with the time measured for complete evacuation of the glass burette from the fuel sample feeding the engine. For every fuel change, the fuel lines are cleaned and the engine left to run for at least $30 \mathrm{~min}$ to stabilize on the new conditions. A large air box fitted with an orifice plate is used for measuring air consumption rate using differential pressure transducer model Setra 239 having differential pressure range of $0-12.7 \mathrm{~cm}$ water column with accuracy of $1 \%$. The exhaust gases temperature is measured using calibrated $\mathrm{K}$ type thermocouple with accuracy of $\pm 0.5 \%$. Ambient air temperature, intake air temperature is measured using calibrated $\mathrm{K}$ type thermocouple probes. The in cylinder pressure is measured using piezoelectric pressure transducer model Kistler $6123,0-200$ bar as pressure rang with sensitivity of $16.5 \mathrm{pc} / \mathrm{bar}$ and accuracy of $1.118 \%$. A slotted disk is fitted to the end of the crankshaft and an optical sensor for measuring engine speed and crankshaft angle position.

The signals from the pressure transducers, optical sensors, and thermocouples are digitised and recorded in PC with the help of Lab View software for later analysis using a data acquisition card model CIO-DAS1602/12, 12-bit, 32 channel single-ended 16 differentials. The signal of cylinder pressure is acquired for every $0.1^{\circ} \mathrm{CA}$ and the acquisition process covered 50 completed cycles, the average value of these 50 cycles being output the pressure data used for calculation of combustion parameters. The bmep was calculated from engine power, speed and configuration specification. The emission measuring system consists of a water cooled exhaust gas sampler and an ANAPOLE EU200 self calibration exhaust gas analyzer. The exhaust gas sample is sucked by a membrane pump and distributed to different built in electrochemical sensing cells through a water separator. The outgoing signals of the cells are manipulated and digitized by a built in A/D converter. Digital readouts of $\mathrm{CO}_{2}, \mathrm{CO}$, and $\mathrm{NO}_{\mathrm{x}}$ are available through the analyzer screen. The effect of bio-diesel on $\mathrm{PM} /$ soot/smoke is not included in the present study due to no facility for measuring these parameters. 


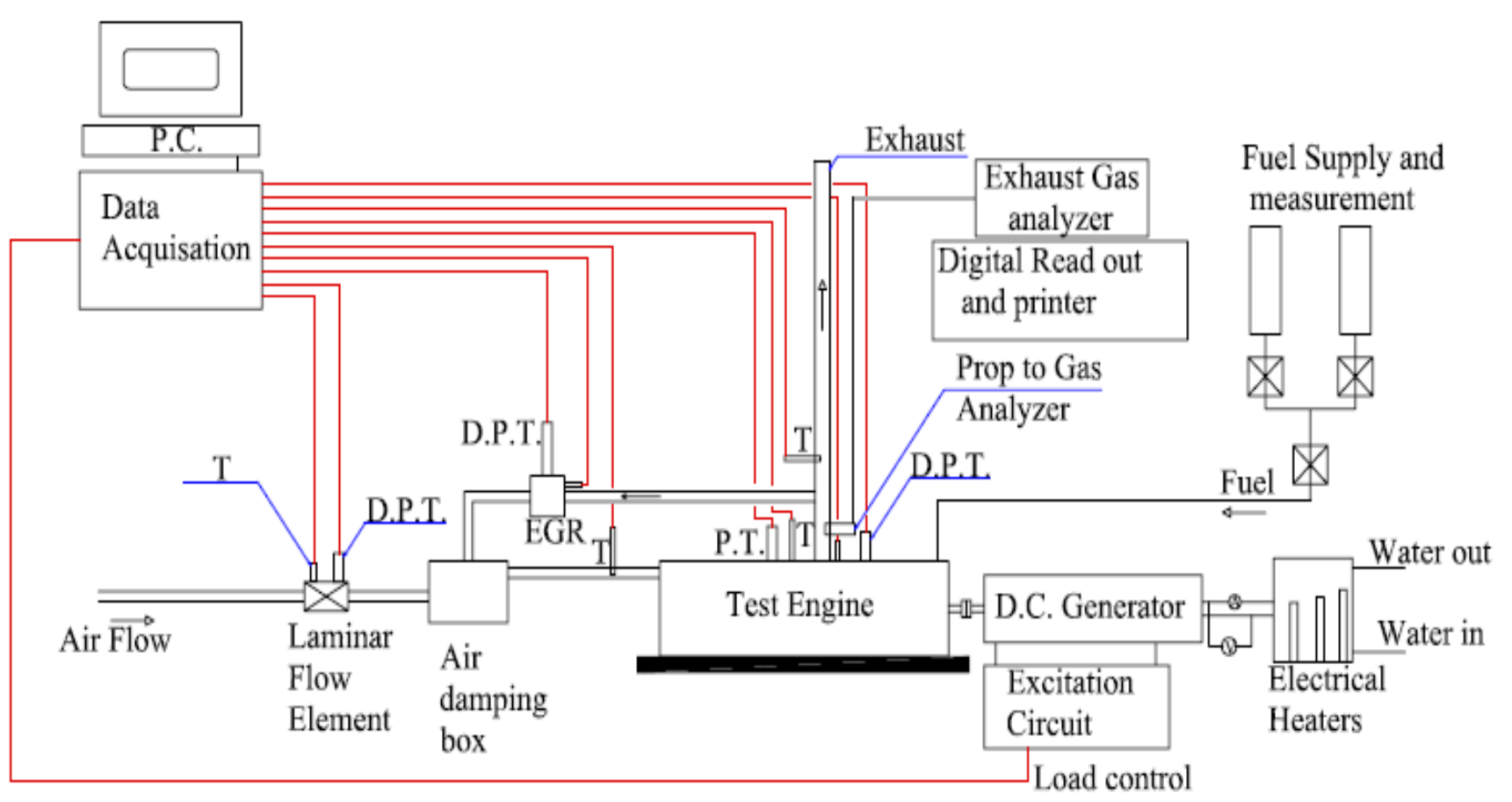

D.P.T. $=$ Differential Pressure Transducer

Fig.(1) Experimental Setup

Part of the exhaust gas is to be recirculated and put back to engine cylinder along with the intake air. Exhaust gas recirculation (EGR) was accomplished by direct link between the exhaust and the intake surge tank. Therefore, the exhaust back pressure is maintained slightly above the intake manifold pressure such that exhaust gas recirculation could occur. The quantity of this EGR was measured and controlled accurately; hence a by-pass for the exhaust gas is provided along with the manually controlled EGR valve in the circulation line between the exhaust gas manifold and the intake surge tank. The exhaust gas comes out of the engine during the exhaust stroke at high pressure. It is pulsating in nature. It is desirable to remove these pulses in order to make the volumetric flow rate measurements of the recirculating gas possible. For this purpose, EGR was directed to air box line before entering engine cylinder to improve mixing process with fresh air. An orifice plate was used for measuring EGR flow rate using differential pressure transducer model Setra 239 having differential pressure range of $0-12.7 \mathrm{~cm}$ water column with accuracy of $1 \%$. The detailed schematic line drawing of the experimental EGR system is shown in Fig.(1). Thermocouples are provided at the intake manifold, exhaust manifold and along the EGR route. Part of exhaust gas with a controlled electrical heater and $J$ type thermocouple are used for heating biodiesel and diesel fuels to $120^{\circ} \mathrm{C}$ before entering the main fuel pump. This work studies the interaction resulting from the application and control of the exhaust gas recirculation (EGR) level and its effectiveness on the development of gaseous emissions as well as engine performance parameters. 


\section{Conditions and Parameters Studied}

The series of tests were conducted using each of the above fuels at different engine speeds at injection timing of $24^{\circ}$ crank angles before top dead center (BTDC). The tests were also conducted at same conditions with changing exhaust gas recirculation rates (EGR) from 0 to $20 \%$ of inlet air fresh charge. Owing to the differences among the heating values and oxygen contents of the fuels tested, the comparison must be affected at the same engine brake mean effective pressure (load). Test matrix of engine operating conditions for different fuels is shown in Table (2). In each test, exhaust gas temperature, oil temperature cylinder wall temperature, inlet air temperature, differential pressure across orifice plate at inlet air box, in cylinder pressure, volumetric fuel consumption, and volumetric dry exhaust regulated gases emissions of $\mathrm{O}_{2}, \mathrm{CO}_{2}, \mathrm{CO}$ and $\mathrm{NO}$ are measured. The analyzer has accuracy of $\pm 1 \%$. From the first measurement, brake specific fuel consumption, brake thermal efficiency, brake mean effective pressure, brake power and volumetric efficiency, are computed. The experimental work started with a preliminary investigation of the engine running on diesel fuel to determine the engine performance parameters characteristics, exhaust emissions, cylinder pressure, oil/wall/exhaust temperatures constituting the baseline. The same procedures were repeated for each fuel at the same operating conditions. For every fuel change, the fuel lines are cleaned and the engine is left to operate for about $30 \mathrm{~min}$ to stabilize at it's the new conditions. The differences in the measured performance parameters, exhaust emissions, cylinder pressure, oil/wall/exhaust temperatures from the base diesel fuel and three other fuels are determined and compared at different operating conditions and various amount of EGR rate from $0 \%$ to $20 \%$.

Table 1. Technical specification of the test diesel engine

\begin{tabular}{|c|c|c|c|}
\hline Type & DEUTZ F1L511 & \multicolumn{2}{|c|}{ Table 2. Engine operating conditions } \\
\hline Cooling type & Air cooled & & \\
\hline Number of cylinders & 1 & \begin{tabular}{|l} 
Parameter \\
Fncinesned PDM
\end{tabular} & Range \\
\hline Number of cycles & 4 & Enginespeed RPM & $800-1600$ \\
\hline Bore $[\mathrm{mm}]$ & $100 \mathrm{~mm}$ & Engine Load \% & $0-100$ \\
\hline Stroke $[\mathrm{mm}]$ & $105 \mathrm{~mm}$ & Injection Timing & 24 Deg. \\
\hline Compression ratio & $17: 1$ & $\mathrm{~T}_{\text {inlet mainfold }}$ & $25^{\circ} \mathrm{C}$ \\
\hline Rated brake power [Kw] & 5.775 at $1500 \mathrm{rpm}$ & $T_{\text {fuel }}$ & $120{ }^{\circ} \mathrm{C}$ \\
\hline Fuel injection advance angle & $24^{0}$ BTDC & EGR \% & $0-20$ \\
\hline Injector opening pressure (bar) & 175 & & \\
\hline Number of nozzle holes & 1 & & \\
\hline Cam profile & Constant velocity & & \\
\hline
\end{tabular}

\section{4-Esterification Procedure}

Biodiesel oil in the flask was heated on a heating mantle with a mechanical stirrer arrangement. The mixture (methanol and Biodiesel seed oil) was continuously stirred in the air closed reaction flask for 120 minutes at $65{ }^{\circ} \mathrm{C}$ with a stirring speed of $450 \mathrm{rpm}$. The temperature in the apparatus should be maintained just above the boiling point of alcohol of 
$65{ }^{\circ} \mathrm{C}$ to accomplish the reaction. Alcohol in vegetable oils affects the conversion efficiency of the process. For the stoichiorametic transesterification, 3 moles' of alcohol are required for each mole of the oil. However, in practice, the molar ratio should be higher than this theoretical ratio in order to derive the reaction towards early completion. Sulphuric acid is used as catalyst in the acid- catalyst pretreatment. Experimentally it is optimized that $1 \%$ by volume of the sulphuric acid and a molar ratio of 6:1 gives the maximum conversion efficiency. The products of the first stage are used as input for alkaline process. A molar ratio of $9: 1$ and $1.5 \%$ by weight of $\mathrm{NaOH}$ is found to give the maximum ester yield. With the completion of the reaction, the products were allowed to separate into two layers. The lower layers contained impurities and glycerol. The top ester layer is separated and purified by using distilled water (10\% by volume). Hot distilled water is sprayed over the ester, stirred gently and allowed to settle in the separating funnel. After washing, the final product was heated up to $70{ }^{\circ} \mathrm{C}$ for 15 min under vacuum condition resulting in a clear amber-light yellow liquid with a viscosity comparable to diesel and then stored for further use.

\section{FUEL PROPERTIES}

The conventional diesel fuel (No. 2 D), was supplied by a local petroleum company formed the baseline fuel of the present study. The cotton, palm and flax oils used in this work, obtained from a local oil factory, it is refined, no additives are used, nor the sample subjected to any further refining processes. Fuels properties of cotton, palm and flax are determined according to standard ASTM and IP methods and results given in Table (3).

Viscosity and Density for cotton, palm flax and diesel fuels in temperature range of $298.15 \mathrm{~K}$ to $453.15 \mathrm{~K}$ are measured and the results are shown in Figs (2\&3). Viscosity is a measure of the internal fluid friction or resistance of oil to flow, which tends to oppose any dynamic change in the fluid motion, affects the atomization of a fuel upon injection into the combustion chamber and thereby, ultimately, the formation of engine deposits. It is also important for the flow of oil through pipelines, injector nozzles, and orifices. Fuel viscosity impacts on injection and combustion higher drag and higher pressures affect timing of fuel injection and ignition. High viscosity is the major fuel property explaining why neat vegetable oils have largely been abandoned as an alternative diesel fuel. High viscosity leads to poorer atomization of the fuel spray and less accurate operation of the fuel injectors. The lower viscosity of the oil, the easier it is to pump and atomize and achieve finer droplets. Vegetable oils are extremely viscous with viscosities 10 to 20 times greater than that of diesel fuel. The ability to flow at low temperatures is an actual problem of diesel and biodiesel fuels.

Density has importance in diesel-engine performance since fuel injection operates on a volume metering system. Density of different oils is measured at different temperatures by using relative density bottle. The density of oil changes slightly in the $3^{\text {rd }}$ decimal place with temperature difference $5 \mathrm{~K}$. Viscosities and densities were measured as a function of oil temperatures. Each measurement is recorded at least three times to ensure the reproducibility in the observations.

The viscosity values for cotton, palm and flax are higher than that of diesel fuel at $40^{\circ} \mathrm{C}$ respectively which indicates the significant effect of temperature on viscosity of biodiesel 
fuels. The high viscosity of biodiesel fuel may be due to higher molecular attraction of the long chains of its glyceride molecules. The heating values of biodiesel oil are found nearer to diesel fuel in comparison with other liquid fuel options like ethanol and methanol. The carbon residue of biodiesel fuels are higher than that of the limit specified for grade diesels No. 2 and this may increase the chances of carbon deposition in the combustion chamber. The higher carbon residue may be due to difference in chemical composition and molecular structure of biodiesel fuels. The pour points of biodiesel fuels are higher in comparison with diesel. This may be due to higher percentage of saturated fatty acids in biodiesel fuels. However, being temperate climate in Egypt, the higher pour point may not pose any problem except in cold weather conditions. The ash content of biodiesel fuels are also higher than the limits specified for grade diesel No. 2. The flash points of biodiesel fuel are high as compared to diesel thus indicating its low volatile nature. The firing points of biodiesel fuel are very high as compared to diesel thus indicating its very safe in storing than diesel fuel. The water content was present in only trace amount in both the fuels. The distillation temperature range of biodiesel fuel found lower as compared to diesel. The high flash point temperature of biodiesel fuels are a beneficial safety feature, as the fuels can be safely stored and transported at the room temperature. The cetane number $(\mathrm{CN})$ of biodiesel fuels prohibits its direct use as the alternative fuel in diesel engines, because most of the determined properties of the biodiesel fuels are very close to the diesel fuel. Viscosity increases with chain length (number of carbon atoms) and with increasing degree of saturation. This holds also for the alcohol moiety because the viscosity of ethyl esters is slightly higher than that of methyl esters. Factors such as double-bond configuration influence viscosity whereas double-bond position affects viscosity less.

Viscosity dependence on temperature is a very important characteristic of each fuel, because transport means are exploited in a wide range of climatic conditions. Viscosity of fuel influences the injection of fuel, the quality of filtering and fuel supply through tubes. Viscosity decreases with the increase of temperature; it influences the decrease of the quality of fuel injection, what in turn increases the emission of non-combusted products and decreases the quality of lubrication conditions of diesel parts. Higher viscosity of biodiesel decreases the leakages of fuel in a plunger pair and in turn it changes the parameters of a fuel supply process: injected quantity of fuel, real advanced angle of fuel injection what directly influences an indicating process and harmful emission of exhaust gases. The dependence of viscosity of biodiesel on temperature must be taken into account for solving the tasks of practical application of biodiesels, because at lower than $273 \mathrm{~K}$ temperature the viscosity of biodiesel significantly increases and the reason of it is the crystallisation of saturated methyl esters. 
Table 3. Fuel properties

\begin{tabular}{|c|c|c|c|c|c|}
\hline Properties & Methods & Diesel & Cotton & Palm & Flax \\
\hline $\begin{array}{l}\text { Kinematic Viscosity, at } 40 \\
{ }^{\circ} \mathrm{C} \text { cSt }\end{array}$ & $\begin{array}{l}\text { ASTM D } \\
445\end{array}$ & 4.3 & 6.4 & 7.2 & 8.3 \\
\hline Heating value, $\mathrm{MJ} / \mathrm{Kg}$ & $\begin{array}{l}\text { ASTM D } \\
270\end{array}$ & 43.4 & 39.5 & 39.07 & 39.7 \\
\hline Density, at $15^{0} \mathrm{C}, \mathrm{Kg} / \mathrm{m}^{3}$ & $\begin{array}{l}\text { ASTM D } \\
1298\end{array}$ & 815 & 835 & 855 & 870 \\
\hline Cetane number & $\begin{array}{l}\text { ASTM D } \\
976\end{array}$ & 47.0 & 48.1 & 62 & 53.9 \\
\hline Distillation range $(\mathrm{K})$ & & $\begin{array}{l}460 \text { to } \\
620\end{array}$ & $\begin{array}{c}443-62 \\
8\end{array}$ & $\begin{array}{l}586- \\
559\end{array}$ & $\begin{array}{l}438- \\
638\end{array}$ \\
\hline Iodine Value (IV), $\mathrm{g} / 100 \mathrm{~g}[$ & & $<6$ & $90-119$ & $35-61$ & 122.5 \\
\hline Saponification value (SV) & & 00 & 193.5 & 200.5 & 190 \\
\hline Flash point, $\mathrm{K}$ & $\begin{array}{l}\text { ASTM D } \\
92 / 93\end{array}$ & 329 & 347 & 358 & 355 \\
\hline Pour point, $\mathrm{K}$ & ASTM D 97 & 253 & 269 & 289 & 264 \\
\hline Cloud point, $\mathrm{K}$ & $\begin{array}{l}\text { ASTM D } \\
2500\end{array}$ & 265 & 269 & 286 & 273 \\
\hline Sulfur content, $\quad \mathrm{mg} / \mathrm{kg}$ & IP 336 & $\begin{array}{l}0.03- \\
0.06\end{array}$ & $\begin{array}{c}0.008- \\
0.01\end{array}$ & 00 & $\begin{array}{c}0.008 \\
0.01\end{array}$ \\
\hline $\begin{array}{l}\text { Elemental analysis } \\
(\% \text { WM }) \\
\mathrm{C} \\
\mathrm{H} \\
\mathrm{O} \\
\mathrm{N} \\
\mathrm{S}\end{array}$ & & $\begin{array}{c}80.33 \\
12.3 \\
1.19 \\
1.76 \\
0.25\end{array}$ & $\begin{array}{c}81.42 \\
11.28 \\
7.22 \\
0.028 \\
0.053\end{array}$ & $\begin{array}{c}76.11 \\
10.52 \\
11.06 \\
0.0 \\
0.0\end{array}$ & $\begin{array}{c}81.72 \\
11.02 \\
7.20 \\
0.038 \\
0.054\end{array}$ \\
\hline
\end{tabular}

The viscosity and density decrease as temperature increases. The highest values for viscosity and density are found in the case of flax fuel. Diesel fuel has the lowest viscosities and densities compared to cotton, palm and flax respectively. The difference between viscosity of biodiesel fuels and diesel fuel are maximum at lower temperature and minimum at higher temperature. At temperature of $120{ }^{\circ} \mathrm{C}$ the difference in viscosity for all fuel are the minimum values. So, this temperature is chosen to be the operating temperature for different fuels to decrease viscosity effects on the results. Empirical correlation of density and dynamic viscosity as function in temperature are carried out from the experimental data as follows:-

$$
\rho\left(k g / m^{3}\right)=a+a_{1} T+a_{2} T^{2}+a_{3} T^{3} \quad(1) \quad v(c S T)=b+b_{1} T+b_{2} T^{2}+b_{3} T^{3}
$$

The correlation constants are presented in Table (4). Density and viscosity are calculated using eqs (1\&2) deviates from the experimental results by less than $1 \%$. Different methods such as fuel preheating and transesterificatio Nwafor (2003) and Ghadge (2005) are being used to reduce the viscosity and to produce biodiesel suitable for diesel engine applications. 
Table 4. Density and Viscosity Correlations Constant $\left(a_{i} / b_{i}\right)$ for Different Fuels.

\begin{tabular}{|l|l|l|l|l|}
\hline & \multicolumn{1}{|c|}{ Diesel } & \multicolumn{1}{c|}{ Cotton } & \multicolumn{1}{c|}{ Palm } & \multicolumn{1}{c|}{ Flax } \\
\hline $\mathrm{a} / \mathrm{b}$ & $856.96 / 41.9907$ & $935.61 /$ & $935.61 / 53.0464$ & $882.4 / 60.6798$ \\
& & 59.4756 & & \\
\hline $\mathrm{a}_{1} / \mathrm{b}_{1}$ & $-1.6193 /-$ & $-2.1224 /-$ & $-2.1224 /-1.0069$ & $-0.3937 /-$ \\
& 0.6967 & 1.0069 & & 0.9244 \\
\hline $\mathrm{a}_{2} / \mathrm{b}_{2}$ & $0.0117 /$ & $0.0215 /$ & $0.0215 / 2.8982 \mathrm{E}-$ & $-0.0016 /$ \\
& $5.1869 \mathrm{E}-3$ & $7.9569 \mathrm{E}-3$ & 3 & $6.5354 \mathrm{E}-3$ \\
\hline $\mathrm{a}_{3} / \mathrm{b}_{3}$ & $-4 \mathrm{E}-05 /-$ & $-1 \mathrm{E}-04 /-1 \mathrm{E}-04$ & $-1 \mathrm{E}-04 /-$ & $0.0 /-1.7201 \mathrm{E}-$ \\
& $1.4031 \mathrm{E}-5$ & & $1.6596 \mathrm{E}-6$ & 5 \\
\hline
\end{tabular}

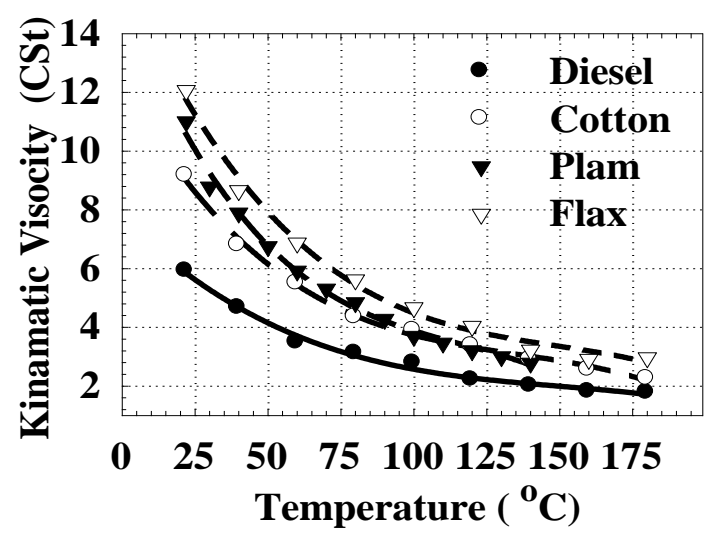

Fig.(2) Viscosity of Different Fuels Versus Temperature

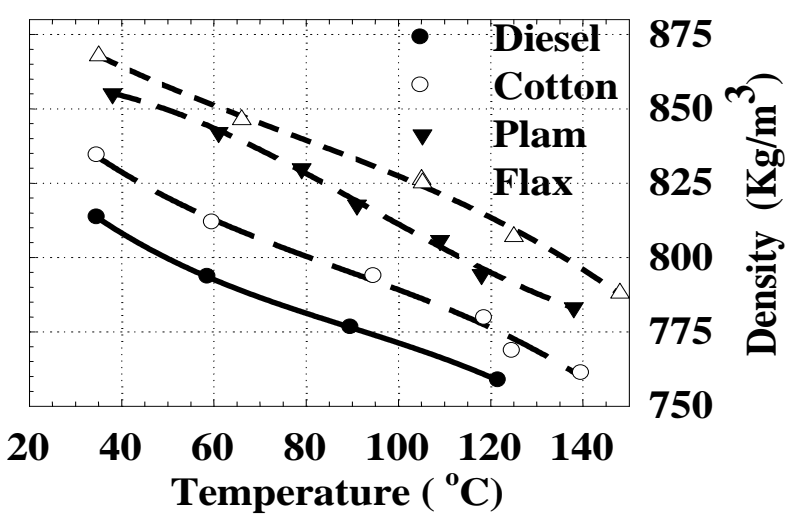

Fig.(3) Density of Different Fuels Versus Temperature

\section{6- RESULTS AND DISCUSSIONS}

\subsection{Fuel Mass Flow Rate and Air/Fuel Ratio}

Fuel mass flow rate for different fuels versus engine speeds are shown in Fig. (4). Fuel mass flow rate for different fuels increases with the increase of engine speed because of mass of fuel is the driving force for energy input to generate power at different engine speed. So, for the same BP output, fuel mass flow rate for biodiesel is higher than diesel fuel due to biodiesel has low heating value. For biodiesel fuels more quantity of fuel are injected per cycle compared to diesel fuel, Devlin et. al. (2008). This phenomenon can be explained by the relationship of specific gravity difference between fuels and pump volumetric efficiency. Plunger begins to vaporize the residual fuel in the chamber of pump cylinder when it ends the pumping stroke, lower biodiesel evaporation in pump cylinder surface results in higher volumetric efficiency of fuel injection pump, hence an increase of the injected fuel quantity. This situation can be related to higher distillation temperature curve of biodiesel, Lin et. al. (2009).

For the same engine speed, biodiesel fuels give fuel mass flow rate higher than diesel fuel a possible explanation is the high viscosity of biodiesel reduces normal injection pump leakage enough to make a significant change in the volume discharged per stroke. Although the 
heating value relationship tends to reduce the specific energy input rate as biodiesel fuel fraction increases (due to increase viscosity) the net effect is an increase in fuel heat supplied. Engine performance parameters and emissions are influenced by basic difference between diesel and biodiesel fuels such as heating value, viscosity, density, cetane number, fuel structure, fuel composition, ...ete. The mass of fuel dependences on viscosity, density, fuel nozzle opening pressure, time and duration of injection. Mass flow rate for different fuels are arrangement in descending order as flax, palm, cotton and diesel respectively which are the same arrangement order for viscosity and density. So, for the same fuel pump stroke, flax has the highest fuel mass flow rate while diesel fuel has the lowest fuel mass flow rate and cotton/palm lay between them due to the highest viscosity, density, injection pressure, minimum fuel leakage for fuel pump plunger, earliest injection timing and longest duration of injection.

Using differential pressure transducer and orifice meter mounted at the entrance to air box, air mass flow rate are measured versus engine crank angle for different fuels (not present). One can observe that air mass flow rate is varied according to opening area of the inlet valve of engine cylinder at different crank angles. Air mass flow rate not go to zero for complete closing of inlet valve due to effect of air box for dissipating pressure waves generated from opening and closing of inlet valve. The area under the curve for each fuel gives the total air mass flow rate for complete cycle. The average air mass flow rate is calculated from the mean value of running 1000 cycles for each fuel. Average air and fuel masses flow rates increase with the increase of engine speed for different fuels. According to BP the average air mass flow rate for different fuels are arrangement in descending order as diesel, flax, palm and cotton respectively.

Air/fuel ratios for different fuels versus engine speed are shown in Fig.(5). Air/fuel ratios for different fuel decrease with the increase of engine speed due to rate of increase fuel flow rate is greater than rate of increase air flow rate. The rate of decreasing air/fuel ratio for different fuels dependences on mass of fuel injected per cycle for each fuel. The mass of fuel per cycle dependences on viscosity, density, fuel nozzle opening pressure, time and duration of injection. Mass flow rate for different fuel are arrangement in descending order are cotton, palm, flax and diesel respectively which are the same arrangement order for BSFC respectively.

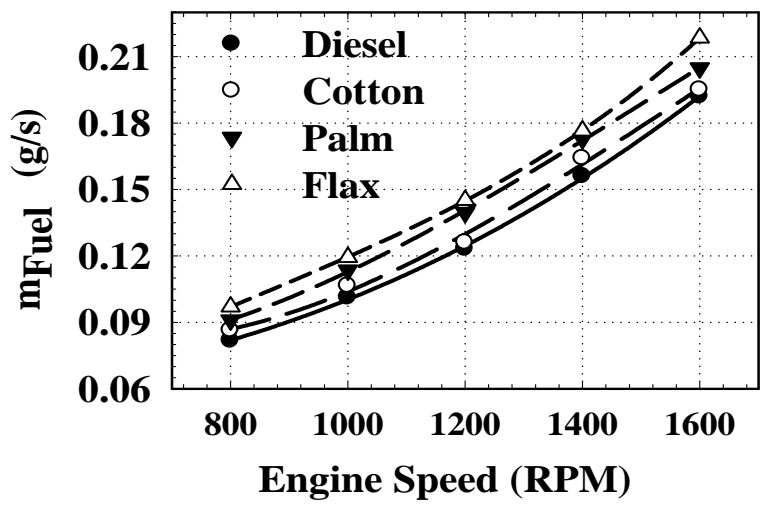

Fig. (4) Fuel Mass Flow Rate for Different Fuels at $75 \%$ Load

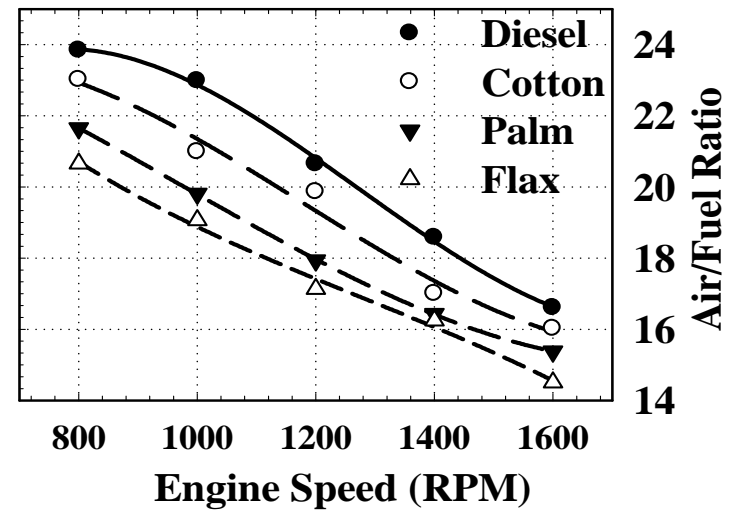

Fig. (5) Air/Fuel Ratio for Different Fuels at $75 \%$ Load 


\subsection{Engine Performance}

The begaining of the present work is focused on finding the effects of preheating on fuel viscosity and consequently on engine performance and emissions. Results show that preheating of biodiesel fuel decreased viscosity and provided smooth fuel flow, avoid fuel filter clogging and improves atomization process of biodiesel fuels. The optimum heating temperatures for all biodiesel are $120{ }^{\circ} \mathrm{C}$ which gives minimum viscosity difference between biodiesel and diesel fuels.

Engine brake power (BP) and brake thermal efficiency $\left(\eta_{B}\right)$ versus engine speeds are shown in Figs.(6\&7). For all tested fuels, BP increases with the increase of engine speed due to increase mass of fuel burning. Also, $\eta_{B}$ increases with the increase of engine speeds due to the rate of increasing $\mathrm{BP}$ is greater the than the rate of increasing mass of fuel burning. Diesel fuel has the highest BP and $\eta_{B}$ due to (I) highest heating value due to lowest oxygen content in molecules, (II) and lowest viscosity which affects atomization process and combustion characteristics and (III) Less heat losses. BP and $\eta_{B}$ of different biodiesel fuels are arrangement in descending order according to their viscosity and oxygen content in biodiesel molecules. High viscosity decreases combustion quality due to large mean droplet diameter of fuel distribution leading to poor fuel atomization process. On other hand oxygen content in biodiesel molecules improves combustion quality and decreases heat of combustion. So, the drop in BP and $\eta_{B}$ with biodiesel fuels than diesel fuel prove that the poor combustion characteristics of the biodiesel fuels due to high viscosity and poor volatility overcomes the excess oxygen present in the biodiesel molecules. The difference in BP between diesel and biodiesel fuels at low engine speed is low than at high engine speed due to increase turbulence intensity and mass of fuel burning. The maximum difference in BP for diesel and biodiesel fuels are arrangement in descending order as cotton (34\%), palm (31\%) and flax $(27 \%)$ respectively. The maximum $\eta_{B}$ are arrangement in descending order as diesel (32.5\%), cotton $(30.5 \%)$, palm (25\%) and flax (24\%) respectively.

Brake specific fuel consumption (BSFC) and volumetric efficiency $\eta_{\vee}$ versus engine speed for different fuels are shown in Figs.(8\&9). BSFC decreases with increase engine speed for different fuels due to rate of increasing BP are greater than rate of increasing fuel consumption. This result indicates a diminishing role of fuel oxygen at high engine speed and hence lower air/fuel ratio and higher turbulence intensity allowing residual air borne oxygen to be available at the final combustion stages. This point of view is further supported by data obtained for the engine running at higher speeds. BSFC for different biodiesel fuels is a higher than that for diesel fuel. This is due to the lower heating values of the biodiesels fuels compared to diesel fuel. The difference in BSFC is maximum at the lowest engine speed of 1000 RPM and decreases to minimum value at maximum engine speed of 1600 RPM 


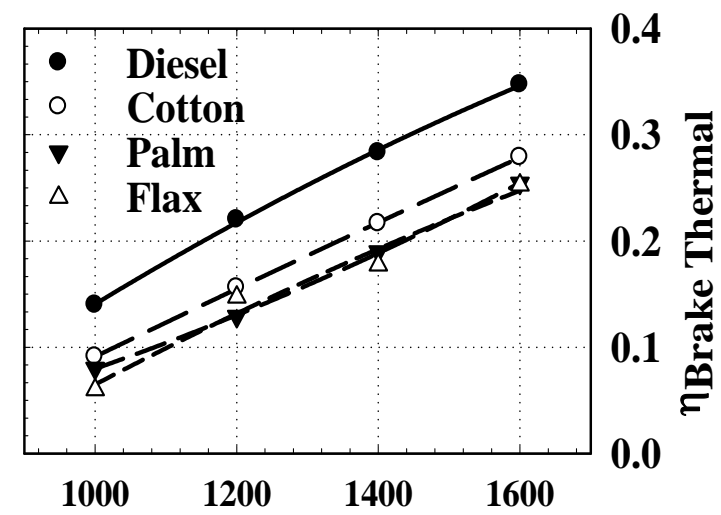

Engine Speed (RPM)

Fig. (7) Brake Thermal Efficiency

\$ for Different Fuels at 75\% Load

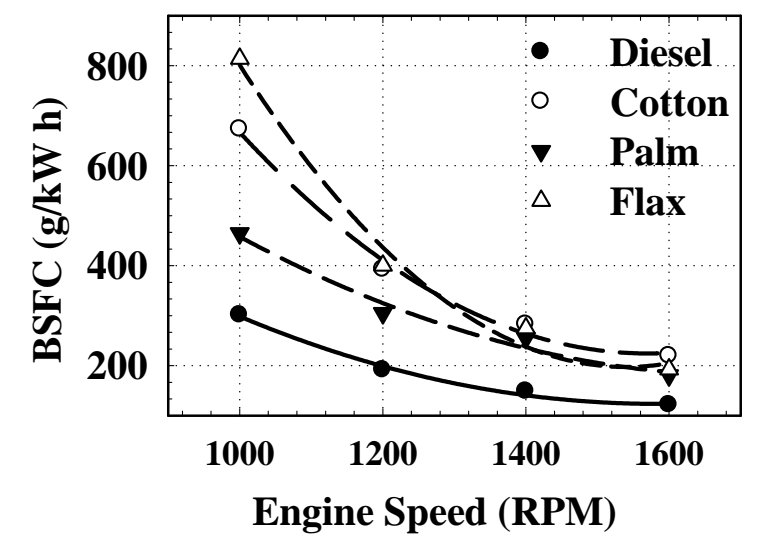

Fig. (8) Brake Specific Fuel Consumption for Different Fuels at $75 \%$ Load

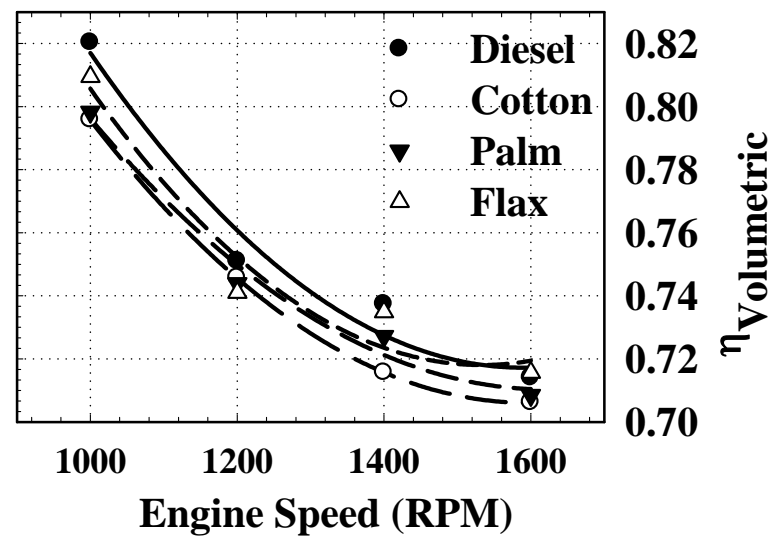

Fig. (9) Volumetric Efficiency for Different Fuels at $75 \%$ Load

Volumetric efficiency $\left(\eta_{v}\right)$ for different fuels decreases with the increase of engine speed. As engine speed increases, entering air into engine cylinder increases due to decrease suction pressure of engine cylinder. But the rate of increasing air mass flow rate is less than the rate of increasing engine speed, so, $\eta_{v}$ decreases with the increase of engine speed. Further increase in speed do not increase air flow rate significantly so volumetric efficiency decreases sharply. This sharp decrease happens because of high speed is accompanied by some phenomenon that have negative influence on $\eta_{v}$. These phenomenon's include the heating of charge in the inlet manifold and high friction flow losses which increases as the square of engine speed. Diesel fuel has the highest $\eta_{v}$ than all biodiesel fuels due to the highest entering air and BP. The engine elements with higher average temperature at high engine speed and load causes air density decreases which decreases $\eta_{v}$ for all tested fuels. 


\subsection{Engine Emissions}

\subsubsection{Effect of engine speeds on emissions}

$\mathrm{O}_{2}$ and $\mathrm{CO}$ concentrations versus engine speed for different fuels are shown in Figs.(10\&11). $\mathrm{O}_{2}$ concentration decreases with the increase of engine speed due to increase mass of fuel burning. $\mathrm{O}_{2}$ concentrations for diesel fuel is lower than that for all biodiesel fuels due to (I) Lower viscosity, good atomization, mixing and combustion quality, (II) Lowest oxygen content in fuel molecules so, combustion process consumed more oxygen from fresh air charge, and (III) The highest heating value which improve heat librated and rate of reactions of different species. $\mathrm{O}_{2}$ concentrations are arranged in descending order as cotton, flax, palm and diesel fuels respectively. $\mathrm{CO}$ emission increases with the increase of engine speeds due to increase mass of fuel burning. This is typical with all internal combustion engines since air/fuel $(A / F)$ ratio decreases with the increase of engine speeds. The diesel fuel produces the highest $\mathrm{CO}$ emissions due to less $\mathrm{O}$ atoms in fuel molecules. At high speed, $\mathrm{CO}$ concentrations increase more rapidly for both diesel and biodiesel fuels. $\mathrm{CO}$ emission is due to incomplete combustion which is most likely to occur at low air/fuel ratios in the engine. Biodiesel is an oxygenated compound which peruses hydrocarbons having a structure that provides a reasonable antiknock value, fuel burning is more efficient and reducing $\mathrm{CO}$ concentration. Consequently, the three biodiesel fuels emitted less $\mathrm{CO}$ concentrations than diesel fuel. Also, CO concentrations are lower for biodiesel fuel due to higher cetane number of three biodiesel fuels than diesel fuel. For biodiesel fuel, oxygen in fuel molecules increases oxidation rate of $\mathrm{CO}$ to $\mathrm{CO}_{2}$ leading to decrease $\mathrm{CO}$ concentrations. $\mathrm{CO}$ concentrations are arrangement in descending order as diesel, palm, cotton and flax respectively. The $\mathrm{CO}$ emissions from burning cotton, palm and flax are $0.27 \%, 0.18 \%$ and $0.37 \%$ respectively from diesel fuel emission.

$\mathrm{CO}_{2}$ and $\mathrm{NO}_{\mathrm{x}}$ concentrations for different fuels versus engine speed are shown in Figs. (12\&13). $\mathrm{CO}_{2}$ concentration increases with the increase of engine speed due to decrease air/fuel ratio towards stoichiometric conditions. The burning gas temperature in the engine cylinder significantly influenced the oxidization rate of $\mathrm{CO}$ emission. A higher burning gas temperature accelerates the oxidization rate of $\mathrm{CO}$ to form $\mathrm{CO}_{2}$ and consequently less $\mathrm{CO}$ concentration in the exhaust gas. Diesel fuel causes a higher burning gas temperature in the engine cylinder and consequently lower $\mathrm{CO}$ concentration than biodiesel fuels. Consequently higher $\mathrm{CO}_{2}$ concentrations for diesel fuel than all biodiesel fuels. Also, $\mathrm{CO}_{2}$ emitted by different biodiesel fuel depend on cylinder gas temperature, fuel viscosity, carbon/hydrogen ratio, and oxygen concentrations in the fuel molecules. The positive effect for three parameters gives the highest concentrations of $\mathrm{CO}_{2} . \mathrm{CO}_{2}$ concentrations for different biodiesel fuels are arrangement in descending order as palm, cotton ad flax fuels respectively. 


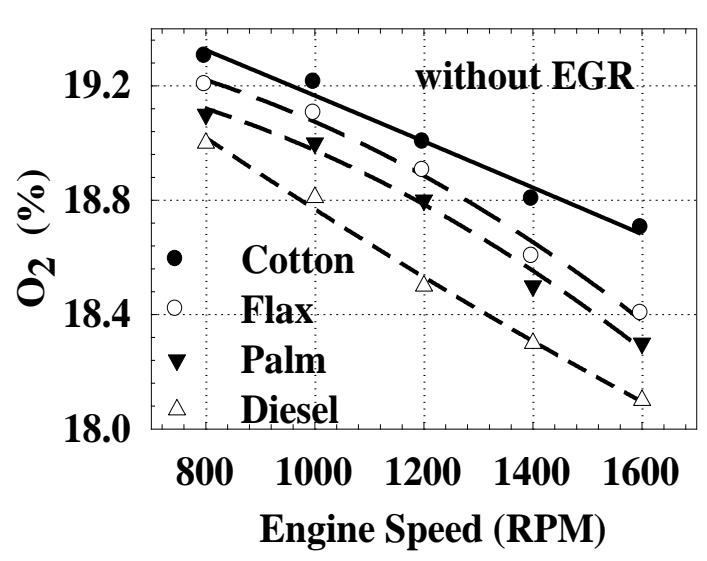

Fig. (10) $\mathrm{O}_{2}$ Versur Engine Speed for Different Fuels at $75 \%$ Load

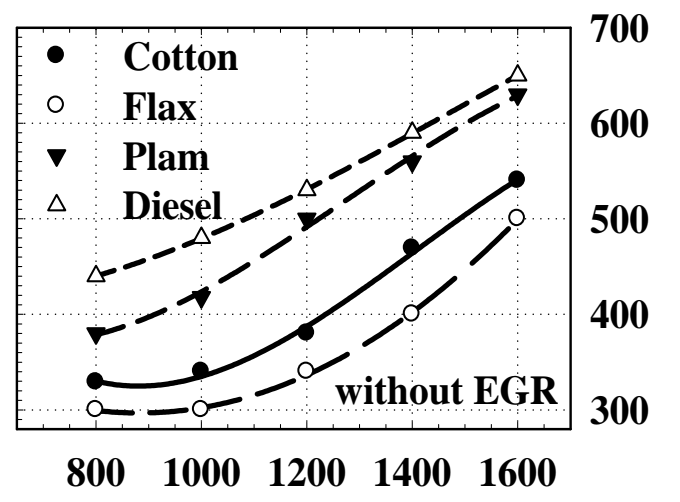

Engine Speed (RPM)

Fig. (11) CO Versus Engine Speed for Different Fuels at $75 \%$ Load

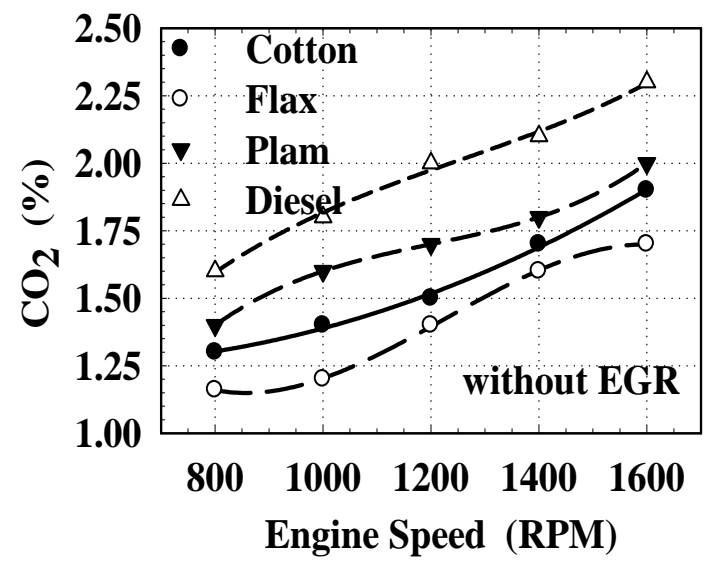

Fig. (12) $\mathrm{CO}_{2}$ Versus Engine Speed for Different Fuels at $75 \%$ Load

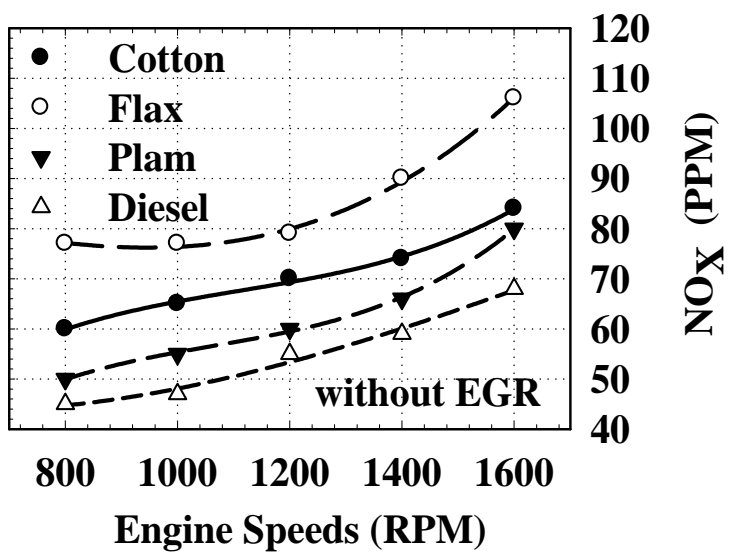

Fig. (13) $\mathrm{NO}_{X}$ Versus Engine Speed for Different Fuels at $75 \%$ Load

$\mathrm{NO}_{x}$ concentration increases with the increase of engine speed due to increase in cylinder gas temperature. $\mathrm{NO}_{x}$ emitted by diesel fuel are lower than that emitted by each one of the three biodiesel fuels. The $\mathrm{NO}_{x}$ emission arguments are palm, cotton and flax respectively. Biodiesel fuels produce lower $\mathrm{NO}_{x}$ concentrations due to the cetane number of the biodiesels are higher than that for diesel fuel. Higher cetane number (as high as 55 to 60) generally improve diesel emissions, but above that level little improvement is demonstrated. Increasing cetane number reduces the size of the premixed combustion by reducing the ignition delay. This results in increase $\mathrm{NO}_{x}$ formation rate since the combustion pressure and temperature rise to maximum values, giving more time for reacting oxygen and nitrogen molecules to form $\mathrm{NO}_{x}$. NOx emissions increase with the increase of unsaturation and decreasing chain length, which can also lead to a connection with the cetane number of these compounds. Cetane number is lower with increasing unsaturation and higher with increasing chain length, i.e., uninterrupted $\mathrm{CH}_{2}$ moieties Also, the cause of the biodiesel $\mathrm{NO}_{x}$ increases, at least for unit injection systems, was shown to be related to a small shift in fuel injection timing caused by the different mechanical properties of biodiesel relative to conventional diesel Tat and Gerpen 
(2003), and Monyem et. al. (2001). Because of the higher bulk modulus of compressibility (or speed of sound) of biodiesel, there is a more rapid transfer of the fuel pump pressure wave to the injector needle, resulting in earlier needle lift and producing a small advance in injection timing, this effect was examined in more detail by Sybist and Boehman (2003). It was found that biodiesel derived B100 produces a $1^{\circ}$ advance in injection timing but a nearly $4^{\circ}$ advance in the start of combustion. The duration of fuel injection was also shorter for biodiesel. $\mathrm{NO}_{\mathrm{x}}$ concentrations increased slightly with biodiesel compared to diesel fuel. The chain length of the compounds has little effect on $\mathrm{NO}_{x}$ emissions, while the influence was greater on $\mathrm{CO}$ and $\mathrm{CO}_{2}$, the latter being reduced with decreasing chain length. Non-saturation in the fatty compounds causes an increase in NOx emissions Knothe et. al., (2006). Higher viscosity and cloud point are a major problem of using biodiesel in diesel engine. These properties affect the fuel droplet size during injection. Biodiesel has both larger viscosity and surface tension, resulting in larger droplets, one of a number of contributing factors that have been identified as possible cases for higher $\mathrm{NO}_{x}$ emissions. The biodiesel impacts on exhaust emissions vary depending on the type of biodiesel fuel. Also, biodiesel increases $\mathrm{NO}_{x}$ concentration due to high radical concentrations of $O$ atoms emitted from biodiesel molecules. The emissions from combusting unrefined palm oil will have elevated levels of $\mathrm{NO}_{x}$ concentrations because of the presence of proteins in the palm tree fruit and so large combustion plant will probably have to include $\mathrm{NO}_{x}$ abatement equipment. Flax fuel gives more $\mathrm{NO}_{x}$ than other biodiesel fuels.

\subsubsection{Effect of exhaust gas recirculation on engine emissions}

$\mathrm{O}_{2}$ and $\mathrm{CO}$ concentrations versus EGR for different fuels are shown in Figs. (14\&15) at engine speed of 1200 RPM and $75 \%$ load. $\mathrm{O}_{2}$ increases with leaner air/fuel mixture. $\mathrm{O}_{2}$ is the opposite of $\mathrm{CO}$ which is $\mathrm{O}_{2}$ indicates leaner air/fuel mixtures while $\mathrm{CO}$ indicates richer air/fuel mixtures. Leaner air/fuel mixtures typically cause high $\mathrm{O}_{2}$ output from the engine. CO concentrations for biodiesel fuels are higher than diesel fuel. For different fuels CO concentrations increase and $\mathrm{O}_{2}$ concentrations decrease as EGR increases due to decrease $\mathrm{O}_{2}$ concentration in the fresh air charge which decreases rate of different reactions. The effect of EGR is caused by increasing amount of inert gas in the mixture, which reduces the adiabatic flame temperature. In other words when the engine operates with high EGR, relative changes of mixture composition due to EGR have impact due to combustion deterioration which is the predominant reason for efficiency losses and increases $\mathrm{CO}$ concentrations. Rate of increasing $\mathrm{CO}$ concentrations at high EGR is greater than that at low EGR due to decrease flame temperature and mixture became richer. Also, $\mathrm{CO}$ emissions for biodiesel fuels are more effect by EGR than diesel fuel. For diesel fuel $\mathrm{O}_{2}$ concentrations is more affected by EGR than for biodiesel fuels due to oxygen content in biodiesel molecules. Also, high percentage of EGR would raise boost pressure and the intake charge temperature. For biodiesel, the excess oxygen content is believed to have partially compensated for the oxygen deficient operation under EGR. CO concentration decrease by (8-7) \%, (24-13)\% and (36$27) \%$ for palm, cotton and flax fuels than diesel fuel respectively when EGR increases from $(4-18) \%$.

Figs. (16\&17) shows the variations of $\mathrm{CO}_{2}$ and $\mathrm{NO}_{x}$ emissions of diesel and biodiesel fuels with EGR. EGR is a process in which a portion of the exhaust gas is recirculated into the intake air. The $\mathrm{CO}_{2}$ and $\mathrm{H}_{2} \mathrm{O}$ in EGR can affect the combustion process in diesel engine in 
three different ways: chemical, thermal, and dilution. The chemical effect stems from the dissociation of $\mathrm{CO}_{2}$ and $\mathrm{H}_{2} \mathrm{O}$ to form free radicals and has only a minor impact on combustion and emissions. The thermal effect arises from the higher specific heat capacity of $\mathrm{CO}_{2}$ and $\mathrm{H}_{2} \mathrm{O}$ relative to the replaced oxygen and also has only an indirect effect on combustion and emissions. The principle influence of EGR on emission associated with combustion is the dilution of the oxygen fraction with $\mathrm{CO}_{2}$ and $\mathrm{H}_{2} \mathrm{O}$ in the inlet charge. As a consequence of the reduced oxygen fraction, the beginning of the combustion process is delayed until the expansion stroke has begun. This delay results in lower $\mathrm{NO}_{x}$ formation since the products of combustion are exposed to high temperature for shorter periods. So, the reasons for reducing $\mathrm{NO}_{\mathrm{x}}$ emissions using EGR are reducing oxygen concentrations and decreasing flame temperatures in the combustion chamber. The effect of EGR on the combustion process is seen as the heat release in premixed combustion phase is reduced due to the reduction in $\mathrm{O}_{2}$ availability associated with the EGR diluents. Moreover, the retardation of the combustion process to a time later in the expansion stroke results in earlier quenching of the combustion process, which leads to a shorter duration of high temperature combustion so that $\mathrm{NO}_{\mathrm{x}}$ has less time to form. The presence of EGR decreases the heat release peak, maximum gas temperature, oxygen concentration and $\mathrm{NO}_{x}$ emission. Negating some of this $\mathrm{NO}_{x}$ reduction, however, is the thermal throttling arising from the increase in the intake charge temperature due to the addition of hot EGR. The change in oxygen concentration causes change in the structure of the flame and hence changes the duration of combustion. It is suggested that flame temperature reduction is the most important factor influencing $\mathrm{NO}_{x}$ formation. The degree of reduction in $\mathrm{NO}_{x}$ is higher at higher EGR. NOx emissions in case of biodiesel fuels are higher than diesel fuel which is combatable with the case of without EGR. Three popular explanations for the effect of EGR on $\mathrm{NO}_{x}$ reduction are increased ignition delay, increased heat capacity and dilution of the intake charge with inert gases. The ignition delay hypothesis asserts that because EGR causes an increase in ignition delay, it has the same effect as retarding the injection timing. The heat capacity hypothesis states that the addition of the inert exhaust gas into the intake manifold increases the heat capacity (specific heat) of the nonreacting matter present during the combustion. The increased heat capacity has the effect of decreasing the peak combustion temperature. According to the dilution theory, the effect of EGR on $\mathrm{NO}_{x}$ is caused by increasing amounts of inert gases in the mixture, which reduces the adiabatic flame temperature. Finally, $\mathrm{NO}_{x}$ emissions increase by (11-17) \% for palm, (44$67) \%$ for cotton and $(55-83) \%$ for flax higher than diesel fuel when EGR increases by (4$18) \%$.

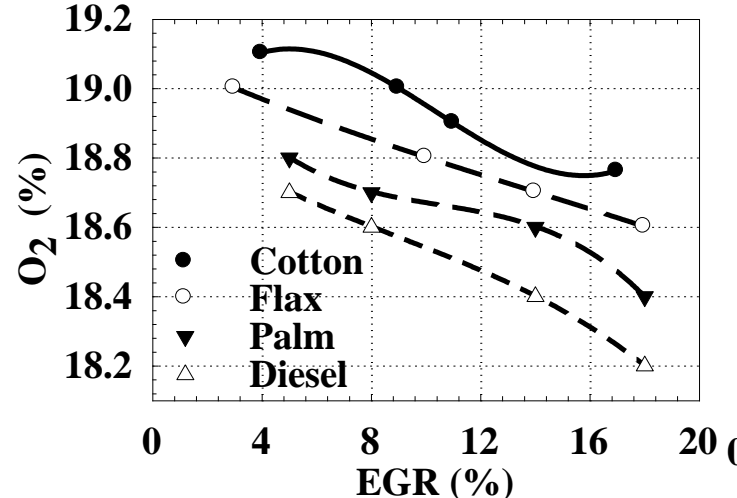

Fig. (14) $\mathrm{O}_{2}$ Versus EGR for Different Fuels at $75 \%$ Load and 1200 RPM

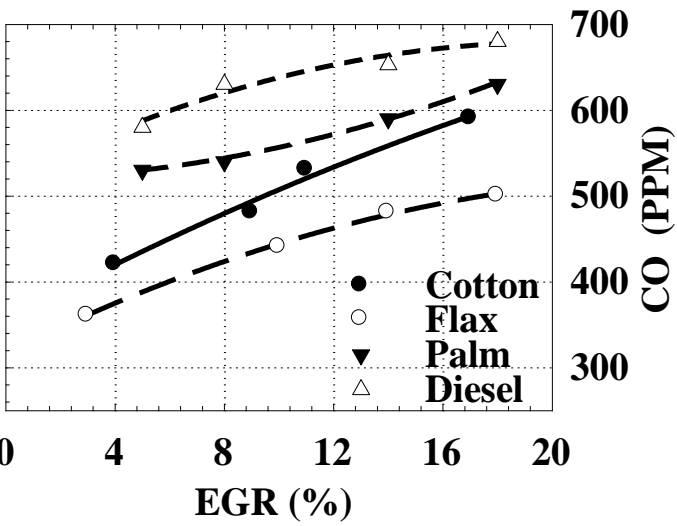

Fig. (15) CO Versus EGR for Different Fuels at $75 \%$ Load and 1200 RPM 


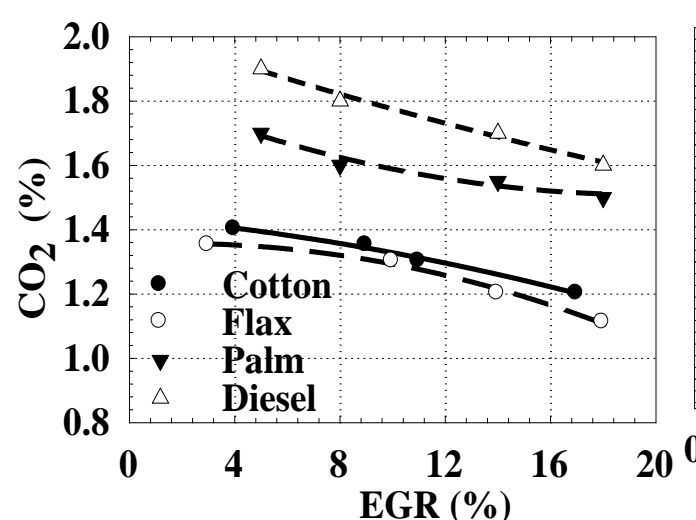

Fig. (16) $\mathrm{CO}_{2}$ Versus EGR for Different

Fuels at $75 \%$ Load and 1200 RPM

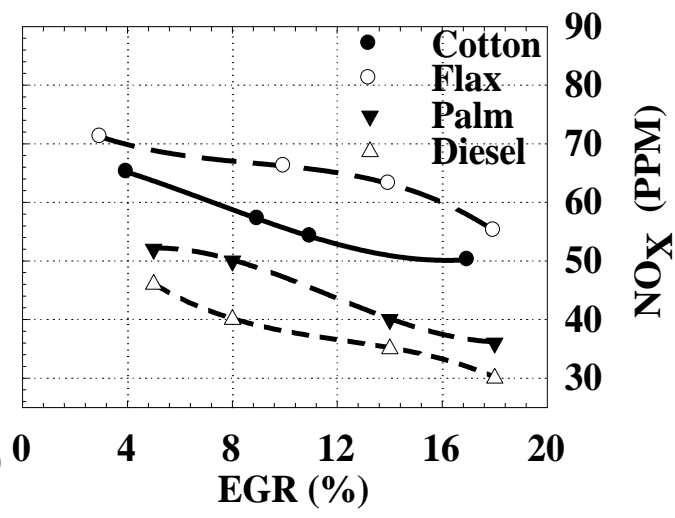

Fig. (17) $\mathrm{NO}_{X}$ Versus EGR for Different Fuels at $75 \%$ Load and 1200 RPM

\subsection{Exhaust, Oil and Wall Temperatures with and Without EGR}

Exhaust gas temperature ( $\left.T_{\text {Exhaust }}\right)$ for diesel and biodiesel fuels with/without $E G R$ are shown in Figs. (18\&19). $T_{\text {Exhaust }}$ gives an indication about the amount of waste heat going with exhaust gas and reflects the status of combustion inside engine cylinder. $T_{\text {Exhaust }}$ increases with increase engine speed and decreases with the increase of EGR for diesel and biodiesel fuels. $T_{\text {Exhaust }}$ increases due to increase ignition delay and quantity of fuel injected. $T_{\text {Exhaust }}$ reduces by adjusting injection timing/injection pressure into the diesel engine. $T_{\text {Exhaust }}$ are lower for EGR due to lower availability of oxygen for combustion and higher specific heat of entering charge to inlet manifold which consider as heat sink for heat generated from combustion process. Diesel fuel has $T_{\text {Exhaust }}$ in between biodiesel fuels with/without EGR. Palm fuel has the highest $T_{\text {Exhaust }}$ while flax fuel has the lowest $T_{\text {Exhaust }}$ with/without $E G R$. As EGR increases from $(0-15) \%$, T Exhaust decreases by $7 \%$ for palm fuel, by $5 \%$ for diesel fuel, by $5 \%$ for cotton and by $6 \%$ for flax fuel.

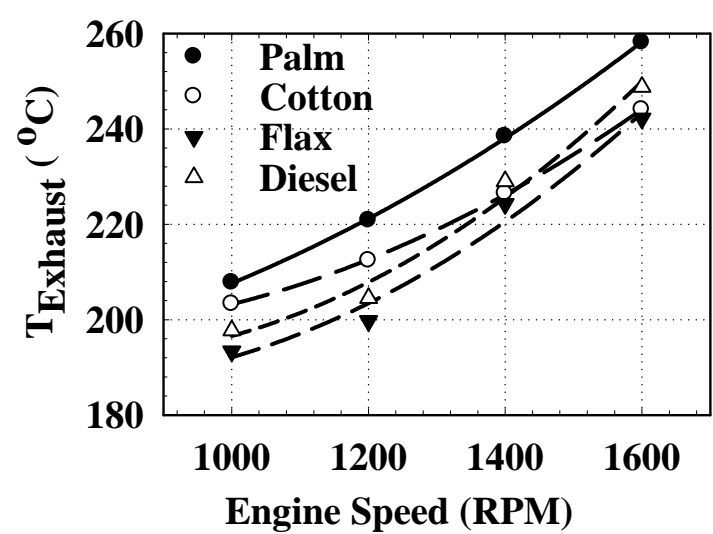

Fig. ( 18) T Exhaust for Different Fuels at 75\% Load Without EGR

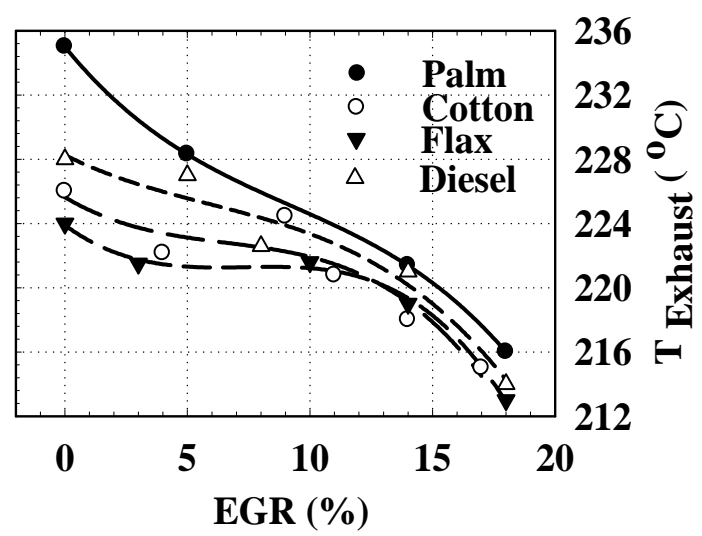

Fig. (19) T Exhaust for Different Fuels at 1400 RPM and $75 \%$ Load 
Oil temperatures ( $\left.T_{\text {Oil }}\right)$ for diesel and biodiesel fuels with/without EGR are shown in Figs. (20 \& 21). Toil gives an indication to the amount of waste heat going with lubricating oil. Also, $T_{\text {Oil }}$ reflects the status of combustion inside the combustion chamber and friction losses between moving pats. Toil decreases with the increase of engine speed and EGR for different fuels. Toil for diesel fuel is lower than biodiesel fuels with/without EGR. The deviation between $T_{\text {oil }}$ for diesel and biodiesel fuels increases with the increase of engine speed and EGR. As EGR increases from $(0-15) \%$ Toil decreases by $5 \%$ for palm, by $12 \%$ for diesel, by $7 \%$ for cotton and by $10 \%$ for flax respectively. From a lubrication standpoint, biodiesels properties render it more likely to enter and remain in the crankcase causing dilution of the lubricating oil. The oxidation of biodiesel in crankcase oil creates increased deposits and lead corrosion.

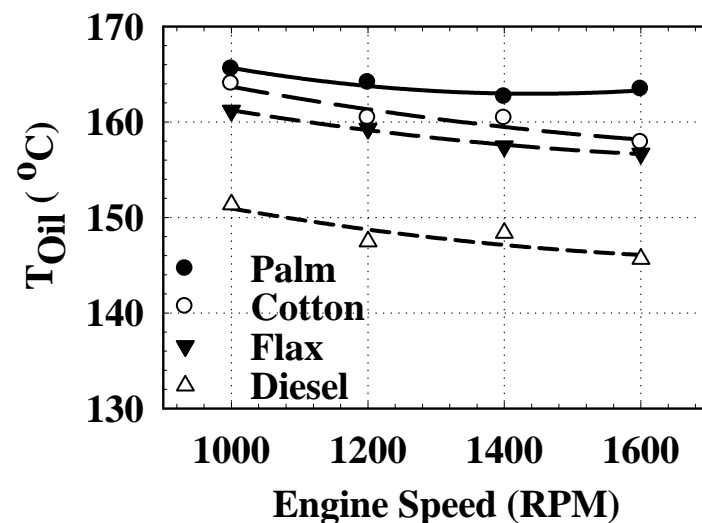

Fig. ( 20) $T_{\text {Oil }}$ for Different Fuels at $75 \%$ Load Without EGR

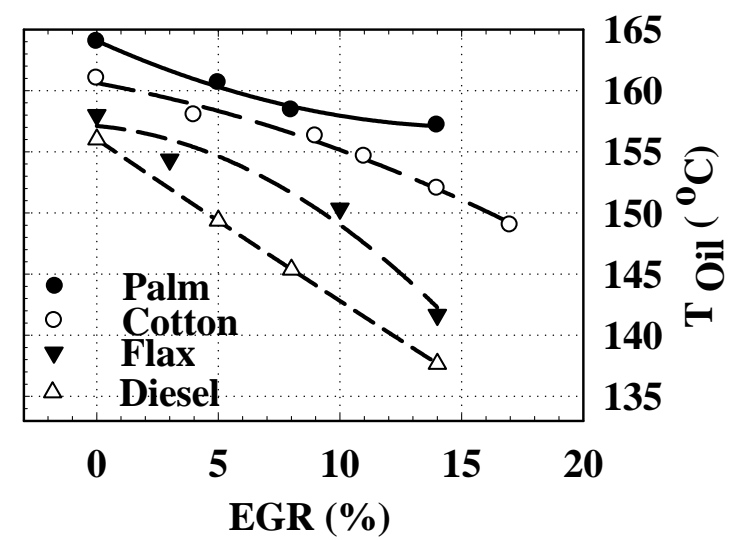

Fig. (21) $T_{\text {Oil }}$ for Different Fuels at 1400 RPM and $75 \%$ Load

Wall temperatures ( $\left.T_{\text {Wall }}\right)$ for diesel and biodiesel fuels with/without EGR are shown in Figs. (22\%23). Twall gives an indication to the amount of waste heat going to engine wall and reflects the status of combustion inside the combustion chamber. Twall for diesel fuel is higher than that for biodiesel fuels due to lubricating effects of biodiesel fuels with/without EGR. The difference in $T_{\text {Wall }}$ for diesel and biodiesel fuels is higher in the case of without $E G R$ than with $E G R$. EGR reduces $T_{\text {wall }}$ due to high heat capacity of $\mathrm{CO}_{2}$ and $\mathrm{H}_{2} \mathrm{O}$ in $E G R$ and flame temperature for case of EGR is lower than without EGR. As EGR increases by $(0 \%-15) \%$, Twall decreases by $2{ }^{\circ} \mathrm{C}$ for palm, by $4{ }^{\circ} \mathrm{C}$ for diesel, by $1^{\circ} \mathrm{C}$ for cotton and by $1.5^{\circ} \mathrm{C}$ for flax respectively. 


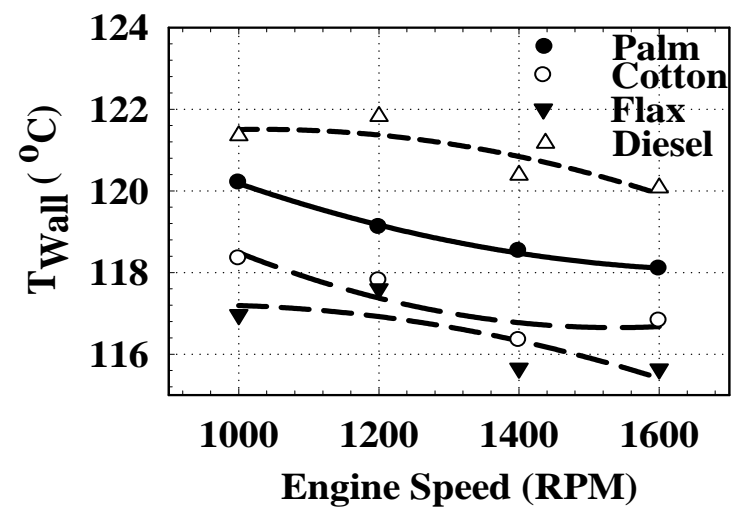

Fig. ( 22) T Tall for Different Fuels at $75 \%$ Load Without EGR

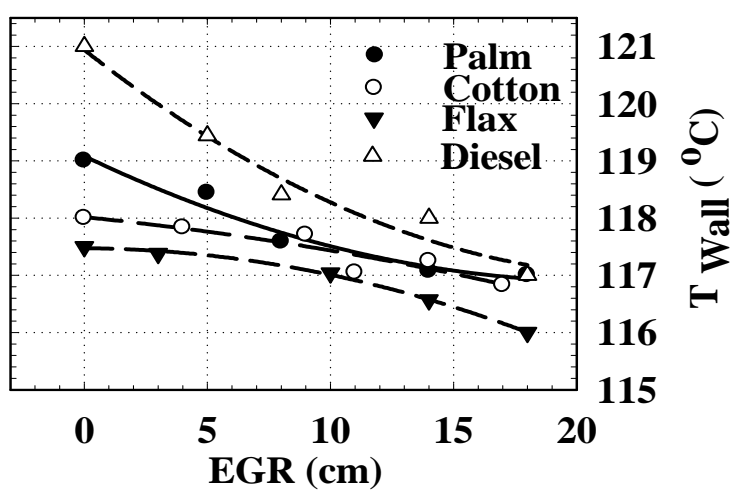

Fig. (23) $\mathbf{T}_{\text {Wall }}$ for Different Fuels at 1400 RPM and $75 \%$ Load

The instantaneous $T_{\text {Exhaust, }} T_{\text {Oil, }}$ and $T_{\text {Wall }}$ are shown in Figs.(24, 25 \&26) respectively. The fluctuation in $T_{\text {Exhaust }}$ is higher than that for $T_{\text {Oil }}$ and $T_{\text {Wall }}$ respectively indicating higher rate of heat losses in exhaust gas than heat losses to oil and engine wall respectively. Palm fuel has maximum temperatures fluctuations in $T_{\text {Exhaust }}, T_{\text {Oil, }}$, and $T_{\text {Wall }}$ while cotton fuel has minimum temperatures fluctuations and flax/diesel fuels lay between them. The temperature fluctuation in $\mathrm{T}_{\text {Exhaust }}$ is $60 \%$ for palm, $50 \%$ for flax, $43 \%$ for diesel and $41 \%$ for cotton from the maximum $\mathrm{T}_{\text {Exhaust }}$ respectively. The temperature fluctuation in $\mathrm{T}_{\text {Oil }}$ is $23 \%$ for palm, $18 \%$ for flax, $12 \%$ for diesel and $8 \%$ for cotton from the maximum $T_{\text {Oil }}$ respectively. The temperature fluctuation in $T_{\text {Wall }}$ is $15 \%$ for palm, $14 \%$ for flax, $12 \%$ for diesel and $6 \%$ for cotton from the maximum $T_{\text {Oil }}$ respectively. This reflects the combustion characteristics of cotton fuel are smoother than flax, diesel and palm respectively. So, combustion noises emitted from engine is higher for palm fuel than flax, diesel and cotton respectively.

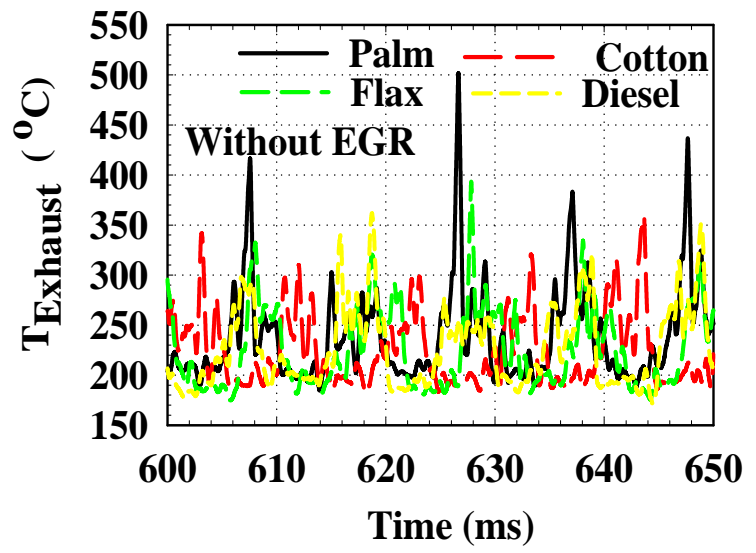

Fig. (24) $T_{\text {Exhaust }}$ for Different Fuels at 75\% Load and 1400 RPM Without EGR

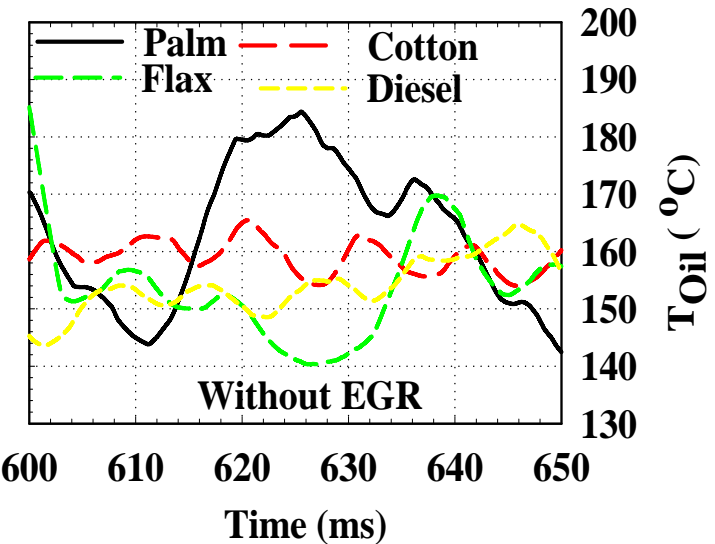

Fig. (25) T Oil for Different Fuels at 75\% Load and 1400 RPM without EGR 


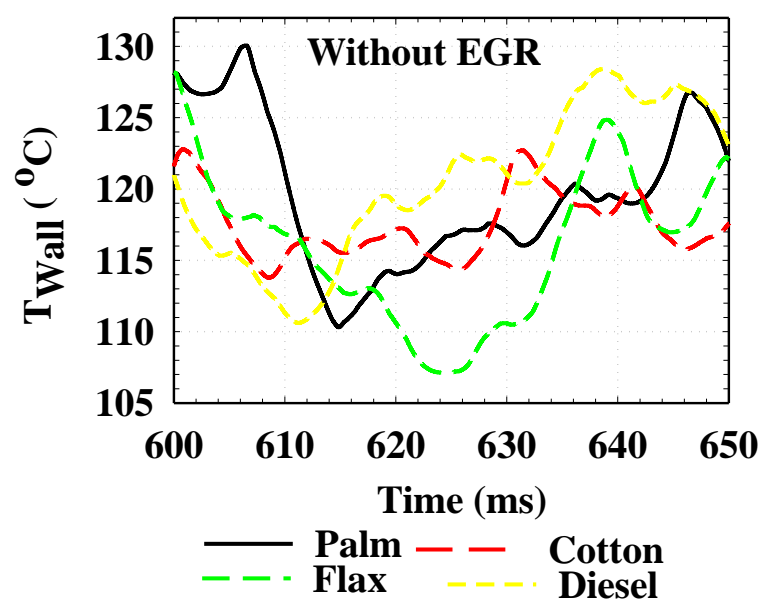

Fig. (26) T Wall for Different Fuels at

$75 \%$ Load and 1400 RPM without EGR

\subsection{Cylinder Pressure}

Effect of engine speeds on engine cylinder pressure for diesel and biodiesel fuels are shown in Figs. (27, 28, 29 \& 30). Overall combustion characteristics for all biodiesel fuels are found quite similar to diesel fuel. In a diesel engine, cylinder pressure depends on the burning fuel fraction during the premixed burning phase, i.e., initial stage of combustion. Cylinder pressure characterizes the ability of the fuel to mix well with air and burns. Since cetane number for diesel fuel is 47 which is lower than biodiesel fuels hence ignition delay is shorter for all biodiesel fuels than diesel fuel. For biodiesel fuels peak pressure decreases with the increase of engine speed. For diesel fuel peak pressure increases with the increase engine speed up to 1400 RPM (condition of maximum power). After that peak pressure decreases with the increase engine speed. Peak pressures for all biodiesel fuels are higher than diesel fuel. The reason for this is the presence of oxygen in the biodiesel results complete combustion of fuel leading to increase in peak temperature and peak pressure. For diesel engine peak pressure depends on the combustion rate in initial stages which in turn influences by the amount of fuel taking part in the uncontrolled combustion phase. The premixed or uncontrolled combustion phase is generated by the ignition delay period and by the mixture preparation during the delay period. Thus higher viscosity and lower volatility of biodiesel fuels which leads to poor atomization and mixture preparation with air and low burning nature of biodiesel fuels during the ignition delay period are the reasons for decreasing peak pressure for biodiesel fuels with the increase of engine speeds. Peak pressures have the arrangement in descending order as flax, palm, cotton and diesel fuels respectively. After burning period, rate of decreasing pressure for diesel fuel is higher than all biodiesel fuels. This is due to presence of oxygen in the biodiesel that makes complete combustion of biodiesel fuels and hence releasing more heat from the gases. Thus, both the peak temperature and pressure of biodiesel fuels are higher than that of diesel fuel. Position of maximum pressure for diesel fuel for different engine speeds are more delayed ATDC than for all biodiesel fuels due to the lowest cetane number and the longest ignition delay period for diesel fuel. Also, biodiesel fuel produces a $1^{\circ}$ advance in injection timing which is a nearly $4^{\circ}$ advance in the start of combustion. The duration of fuel injection was also shorter for biodiesel consequently biodiesel fuels can complete the combustion before diesel fuel. The position of maximum cylinder pressure are 
arrangement as 11 crank angles (CA) after top dead center (ATDC) for flax, 12 CA degree ATDC for cotton, $14 \mathrm{CA}$ degree ATDC for palm and $20 \mathrm{CA}$ degree ATDC for diesel fuel respectively. The rate of increasing cylinder pressure after ignition and rate of decreasing cylinder pressure after complete combustion are arrangement in descending order as flax, cotton, palm and diesel respectively (flax fuel has the highest rate and diesel has the lowest rate of pressure change).

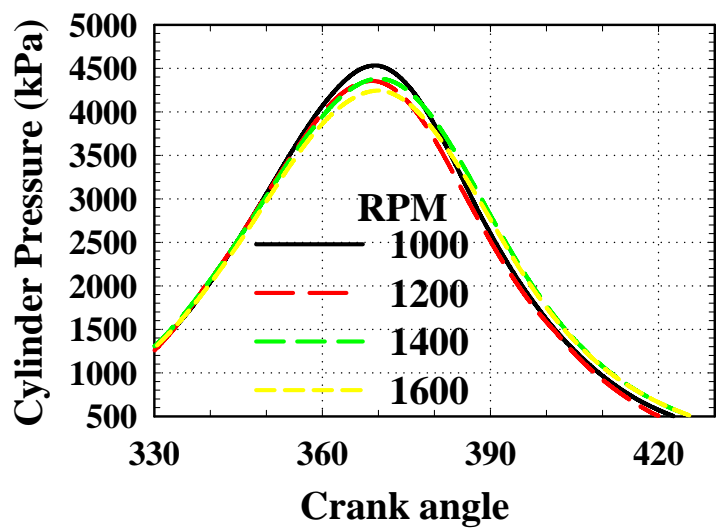

Fig. (27) Cylinder Pressure Using Cotton Fuel at $75 \%$ Load with different Speeds Without EGR

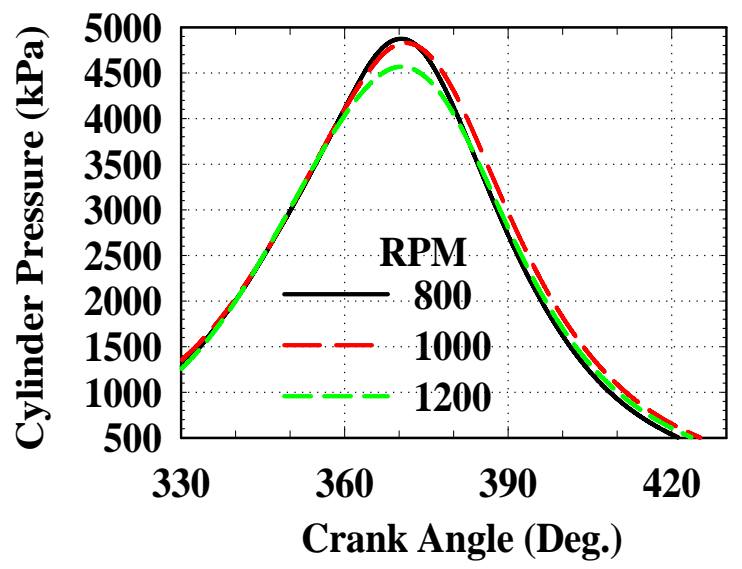

Fig. (29) Cylinder Pressure Using Flax Fuel at $75 \%$ Load and Different Speeds Without EGR

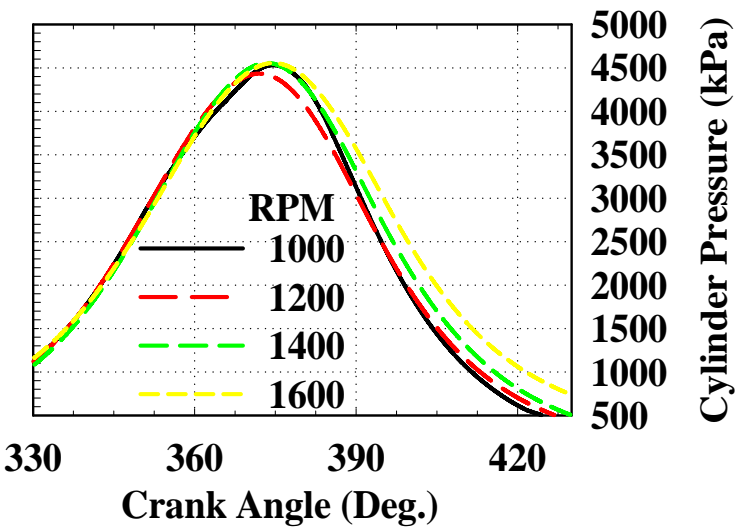

Fig. (28) Cylinder Pressure Using Palm Fuel at $75 \%$ Load with Different Speeds Without EGR

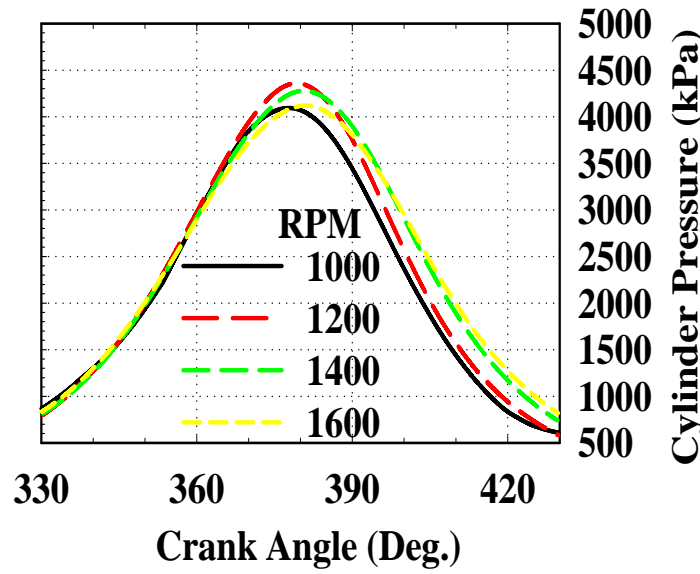

Fig. (30) Cylinder Pressure Using Diesel Fuel at $75 \%$ Load with Different Speeds Without EGR

\section{Conclusions}

1- $\quad$ Temperature of $120{ }^{\circ} \mathrm{C}$ is the suitable temperature giving minimum viscosity difference between diesel and biodiesel fuels as cotton palm and flax.

2- Biodiesel inject fuel mass flow rate higher than diesel fuel due to higher viscosity. Biodiesel reduces normal injection pump leakage making a significant change in the volume discharged per stroke. 
3- Biodiesel fuels gives slightly less $B P$ and $\eta B$ due to low heating value, high viscosity and poor atomization which effect combustion characteristics. Biodiesel gives higher BSFC than diesel fuel due to higher mass of fuel burning. The maximum difference in BP between diesel and biodiesel fuels are arrangement in descending order as cotton (34\%), palm (30\%) and flax (24\%) respectively. The maximum thermal efficiencies are arrangement in descending order as diesel (32.5\%), flax (30.5\%), cotton (29\%) and Palm (24\%) respectively.

4- Biodiesel reduces $\mathrm{CO}$ and $\mathrm{CO} 2$ emissions and increases NOX emissions due to high cetane number and high radical concentrations of $O$ atoms emitted from biodiesel molecules. Biodiesel inject fuel mass flow rate higher than diesel fuel due to higher viscosity. Biodiesel reduces normal injection pump leakage making a significant change in the volume discharged per stroke. NOX concentration decreases with the increase of EGR due to the retardation of the combustion process to a time later in the expansion stroke. This results in earlier quenching of the combustion gases, which leads to a shorter duration of high temperature combustion so NOX has less time to form. The presence of EGR decreases heat release peak, gas temperature peak, oxygen concentration, NOX formation and increases $\mathrm{CO}$ concentration. $\mathrm{CO}$ concentration decreases by (8-7)\% for palm, (24-13)\% for cotton and by (36-27)\% for flax respectively when EGR increases by $(4-18) \%$.

5- TExhaust increases with the increase of engine speed and decreases with the increase of EGR for diesel and biodiesel fuels. TExhaust increases due to increase ignition delay and quantity of fuel injected. TOil for diesel fuel is lower than biodiesel fuels with/without EGR. The difference between TOil for diesel and biodiesel fuels increases with the increase of engine speed and EGR. TWall for diesel fuel is higher than that for biodiesel fuels due to lubricating effects of biodiesel fuels with/without EGR. The difference in TWall for diesel and biodiesel fuels is higher in the case of without EGR than with EGR.

6- The fluctuation in TExhaust is higher than that for TOil and TWall respectively indicating higher rate of heat losses in exhaust gas than heat losses to oil and engine wall respectively. Palm fuel has maximum temperature fluctuation in TExhaust, TOil, and TWall while cotton fuel has minimum temperature fluctuation and flax/diesel fuels lay between them.

7- $\quad$ Peak pressures for biodiesel are higher than diesel fuel. The reason is the presence of oxygen in the biodiesel molecules resulting complete combustion of fuel leading to increase in peak temperature and peak pressure. Peak pressures are arrangement in descending order as flax, palm, cotton and diesel fuels respectively. The position of maximum cylinder pressure are arrangement as $11 \mathrm{CA}$ degree ATDC for flax, $12 \mathrm{CA}$ degree ATDC for cotton, 14 CA degree ATDC for palm and 20 CA degree ATDC for diesel fuel respectively. The rate of increasing cylinder pressure after ignition and rate of decreasing cylinder pressure after complete combustion are arrangement in descending order as flax, cotton, palm and diesel respectively (flax fuel has the highest rate while diesel has the lowest rate of pressure change).

\section{References}

1. Bala, B.K. 2005, "Studies on Biodiesels from Transformation of Vegetable Oils for Diesel Engines", Edu Sci Technol 15:1-45. 
2. Devlin, C.C., Passut, C.A., Campbell, R.L. and Jao, T.-C., (2008), "Biodiesel Fuel Effect on Diesel Engine Lubrication", SAE Technical Paper No. 2008-01-2375, 2008.

3. Ghazikhani M., Kalateh R. M., Toroghi K. Y., and Dehnavi M., (2009), "An Experimental Study on the Effect of EGR and Engine Speed on CO and HC Emissions of Dual Fuel $\mathrm{HCCl}$ Engine", World Academy of Science, Engineering and Technology 522009.

4. Ghadge S.V. and R. Hifjur. (2005), "Bio-Diesel Production from Mahua (Madhuca indica) Oil Having High Free Fatty Acids", Journal of Biomass and Bioenergy. 28: 601-605.

5. Knothe G., (2005), "Dependence of Biodiesel Fuel Properties on the Structure of Fatty Acid Alkyl Esters", Fuel Processing Tech., 86, p. 1059-1070.

6. Knothe, G., Sharp, C.A., Ryan, T.W. 2006, "Exhaust Emissions of Biodiesel, Petrodiesel, Neat Methyl Esters, and Alkanes in a new Technology Engine", Energy Fuels 20:403-408.

7. Levent Yüksek, Hakan Kaleli, Orkun Özener, and Berk Özoğuz, (2009), "The Effect and Comparison of Biodiesel-Diesel Fuel on Crankcase Oil, Diesel Engine Performance and Emissions", Faculty of Mechanical Engineering (FME) Transactions 37, pp. 91-97.

8. Lin, L., Ying, D., Chaitep, S. and Vittayapadung, S.,(2009), "Biodiesel Production from Crude Rice Bran Oil and Properties as Fuel”, Applied Energy, Vol. 86, No. 5, pp. 681-688.

9. Monyem, A., J.H. van Gerpen, and M. Canakci, (2001), "The Effect of Timing and Oxidation on Emissions from Biodiesel-Fueled Engines", Trans. ASAE 44: 35-42.

10. Nwafor O.M.I. (2003), "The Effect of Elevated Fuel Inlet Temperature on Performance of Diesel Engine Running on Neat Vegetable Oil at Constant Speed Conditions", Journal of Renewable Energy. 28: 171-181.

11. Shailendra Sinha1 and Mritunjay Kumar Shukla, (2004), "Effect of EGR on the Exhaust Gas Temperature and Exhaust Opacity in Compression Ignition Engines", Sadhana, Vol. 29, Part 3, June 2004, pp. 275-284.

12. Song Charng Kong and Anne Kimber, (2008), "Effects of Biodiesel Blends on the Performance of Large Diesel Engines", Society of Automotive Engineers, Inc., NO. 200801-1389.

13. Sybist, J.P., and A.L. Boehman, (2003), "Behavior of a Diesel Injection System with Biodiesel Fuel", SAE Technical Paper No. 2003-01-1039.

14. Tat, M.E., and Van Gerpen H. J., (2003), "Measurement of Biodiesel Speed of Sound and Its Impact on Injection Timing", National Renewable Energy Laboratory, NREL/SR-51031462, Golden, Company.

15. Tom Beer, Tim Grant and Peter K Campbell, (2007), "The Greenhouse and Air Quality Emissions of Biodiesel Blends in Australia", Report Number KS54C/1/F2.27, August 2007.

16. Rajan K. , and Senthilkumar R. K., (2009), "Effect of Exhaust Gas Recirculation (EGR) on the Performance and Emission Characteristics of Diesel Engine with Sunflower Oil Methyl Ester", Jordan Journal of Mechanical and Industrial Engineering, Volume 3, Number 4, ISSN 1995-6665 Pp. $306-311$.

17. Puppan, D. (2002), "Environmental Evaluation of Biofuels", Periodica Polytechnica Ser Soc Man Sci. 10:95-116.

18. Walke V. P., Deshpande V. N. and Bodkhe G. R., (2008), "Impact of Exhaust Gas Recirculation on the Performances of Diesel Engine", Proceedings of the World Congress on Engineering 2008 Vol II, WCE 2008, July 2 - 4, 2008, London, U.K. 